\title{
Actual Indicator
}

National Cancer Institute

\section{Source}

National Cancer Institute. Actual Indicator. NCI Thesaurus. Code C93500.

Specifies whether the entity is real (actual) versus a placeholder (kind of). 